\title{
Konflik Antar Etnis di Indonesia dalam Analisis Face Negotiation Theory
}

\author{
Muhammad Rachdian Al Azis ${ }^{1}$, Irwansyah ${ }^{2}$ \\ ${ }^{12}$ Departemen Ilmu Komunikasi FISIP, Universitas Indonesia, Jakarta \\ *Corresponding author, e-mail: muhammad.rachdian01@ui.ac.id
}

\begin{abstract}
Indonesia is known as a country with a pluralistic society. With the wealth of ethnicity, ethnicity, race, and religion in it, this multicultural society then becomes prone to friction. Not to mention the differences in terms of language, customs, and habits in it. These frictions will in turn lead to conflicts which are then unavoidable. The study of inter-ethnic conflict in Indonesia in the analysis of face negotiation theory was carried out with several objectives, which are: to explain the analysis of face negotiation theory in several cases of ethnic conflict that occurred in Indonesia so that it is expected to be taken into consideration in preventing or dealing with similar conflicts. The method used in this research is qualitative with data sources obtained through literature study (Creswell, 2012). The result of the research is that in the Indonesian phenomenon, many sources said that usually the way Indonesian people in determining their attitude during conflict are by integration or mutual - face. Where the characteristics in it are Apologize, Private talk, Remain calm, Problem solve, and Respect. This behavior is a characteristic of collectivistic culture that is indeed embraced by Indonesian people in general.
\end{abstract}

Keywords: Face negotiation theory, facework, etnic conflict, culture communication

Received January 14, $2021 \quad$ Revised October 18, $2021 \quad$ Published October 30, 2021

This is an open access article distributed under the Creative Commons 4.0 Attribution License, which permit unrestricted use, distribution, and reproduction in any medium, provided the original work is properly cited. C2018 by author

\section{Pendahuluan}

Selain memiliki status sebagai makhluk individu, sudah menjadi fitrah bagi manusia untuk menjadi makhluk sosial. Fitrah sebagai makhluk sosial menempatkan manusia pada kondisi yang tidak bisa mencukupi segala macam kebutuhannya sendiri. Manusia akan memerlukan manusia lain untuk mencukupi segala aspek dalam dirinya. Baik secara fisik maupun psikis. Maka dalam prosesnya, tentu akan tercipta sebuah interaksi di dalamnya. Kegiatan aksi-reaksi yang kemudian dapat menjadi warna lain dalam kehidupan seorang anak manusia di dalam lingkup masyarakatnya tempat di mana ia bertinggal.

Indonesia dikenal sebagai negara dengan masyarakat yang bersifat majemuk. Dengan kekayaan etnis, suku, ras, dan agama di dalamnya menjadikan masyarakat yang multikultural ini kemudian menjadi rawan akan adanya gesekan. Belum lagi perbedaan dari segi bahasa, adat istiadat, dan juga kebiasaan di dalamnya. Gesekan-gesekan itu pada gilirannya akan menimbulkan konflik yang kemudian tidak dapat terhindarkan. Baik yang bersifat lokal, maupun yang kemudian sampai menyita perhatian publik secara luas.

Hingga saat ini, Indonesia masih mengalami konflik yang bersifat horizontal, termasuk prasangka antar sesama kelompok etnis. Sebagai contoh pada 2019 mahasiswa Papua mengalami diskriminasi yang keberadaannya ditentang oleh warga Jawa Timur dan adanya pelaporan aparat penegak hukum karena adanya kesalahpahaman atas sikap siswa dan dicap sebagai kelompok anti-nasionalis, mengakibatkan gelombang protes dan kerusuhan di Pulau Papua (Pamungkas, 2019 dalam (Indreswari, Eswandani, Purwasito, \& Satyawan, 2020)).

Keadaan tersebut tentu akan menciptakan gangguan, dan bahkan stereotip yang dibenarkan dari budaya yang berbeda. Konflik seperti itu hanya satu dari sekian banyak masalah yang dihadapi dunia maupun Indonesia. Diperlukan upaya untuk membentuk pemahaman tentang 
komunikasi budaya dan rekonsiliasi konflik untuk menegakkan simbol Bhinneka Tunggal Ika Indonesia. Salah satu caranya dengan memahami masalah budaya melalui penggunaan negosiasi wajah antara pemuda sebagaimana adanya diyakini sebagai agen perubahan.

Dalam penelitian tersebut kemudian diyakini bahwa orang Jawa masih memiliki anggapan jika orang-orang dari Indonesia bagian Timur yang notabene hadir sebagai minoritas memiliki temperamen yang kasar dan dikenal sebagai biang keladi atau si pembuat masalah. Di sisi lain, orang Indonesia bagian Timur sendiri menganggap orang Jawa sebagai makhluk yang terlalu lembut dan cenderung menyembunyikan perasaan mereka yang sebenarnya. Hal ini menunjukkan bahwa masih kurangnya pengetahuan antarbudaya ternyata kemudian akan menciptakan gangguan atau bahkan stereotip yang dibenarkan dari budaya yang berbeda (Indreswari, Eswandani, Purwasito, \& Satyawan, 2020).

Juga adanya perbedaan identitas diri dalam masyarakat Jawa yang berstatus transmigran dengan penduduk lokal Melayu di Kabupaten Indragiri Hulu Riau. Perbedaan identitas yang dimaksud adalah perbedaan karakeristik mulai dari bahasa, maupun pengamalan adat-istiadat kebudayaan (Nur \& Yasir, 2019). Penelitian ini membahas bagaimana masyarakat di daerah Desa Kuala Kilan untuk beradaptasi dan berbaur dalam konteks saling toleransi karena demi kepentingan bersama. Yang dikedepankan kemudian adalah bagaimana memelihara wajah yang sopan guna terciptanya keadaan harmonis yang saling memahami dan saling menghargai serta mengurangi potensi konflik. Komunikasi terjalin dengan bahasa pemersatu Bahasa Indonesia.

Kemudian interaksi antara etnis Minang dengan etnis Batak di Kabupaten Bengkalis. Dimana etnis Minang yang kerap menggunakan suara intonasi yang jauh lebih pelan, akan memicu kesalahpahaman dengan etnik Batak yang kemudian dianggap memiliki jiwa premanisme. Itu terbukti dengan intensnya kalimat ancaman maupun ucapan yang bersifat mengandung menyinggung sedangkan, Etnik Batak menganggapnya sebagai hal yang lumrahlumrah saja (Sari \& Salam, 2017). Penelitian ini membahas tentang adanya kesalahan persepsi oleh karena adanya perbedaan bahasa dan mimik muka sebagai bentuk Facework Etnik Batak dan Etnik Minang dalam Interaksi Komunikasi Antarbudaya.

Lalu juga ada pertikaian antara Suku Jawa dengan Suku Kutai yang dipicu perebutan lahan, Cekcok yang terjadi karena kedua belah pihak tidak ada yang mau mengalah dan kentalnya rasa ingin menang sendiri. Disebutkan bahwasannya Suku Kutai yang sebagai putra daerah kemudian merasa adanya rasa didiskriminasi atas kepemilikan tanah. Konflik makin memanas tatkala permasalahan sampai kepada terjadinya pertumpahan darah antar dua suku tersebut. Seorang dari pihak suku Kutai sampai harus mati meregang nyawa oleh karenanya (Putra, Razid, Hairunnisa, \& Sabirudin, 2018). Dan yang terakhir, adanya konflik antar etnis yang membahas pertikaian antara warga perantauan dari Sampang, Madura, dengan penduduk etnis Dayak di Kalimantan beberapa waktu silam (Indreswari, Eswandani, Purwasito, \& Satyawan, 2020).

\section{Tinjauan Kepustakaan}

Artikel ini akan mengkaji sebab-sebab dalam mempergunakan face negotiation theory untuk menganalisa suatu fenomena yang kemudian konsep-konsepnya tidak didiskusikan pada kumpulan artikel penelitian sebelumnya. Untuk kemudian dibahas dalam hasil dan diskusi. Bagaimana analisa penelitian terdahulu dalam mengkategorikan Type of Culture, Self-Construal, Face Concern, dan Conflict Style sebagai upaya identifikasi terhadap penerapan face negotiation theory. Yang kemudian dibahas dalam bentuk literature review dengan pembahasan komprehensif terhadap jamaknya fenomena perbedaan budaya dalam kacamata face negotiation theory.

Teori negosiasi wajah konflik (FNT), seperti yang dikembangkan oleh Stella Ting-Toomey menjelaskan faktor berbasis budaya, berbasis individu, dan situasional yang membentuk kecenderungan komunikator dalam mendekati dan mengelola konflik dalam berbagai situasi (Ting-Toomey, Conflict Face-Negotiation Theory; Tracking Its Evolutionary Journey, 2017). 
Face Negotiation Theory atau Teori Negosiasi Wajah ada untuk kemudian menjelaskan adanya perbedaan-perbedaan budaya guna lebih membantu dalam upaya penanganan adanya konflik dalam penggunaan aspek-aspek komunikasi sebagai ilmu. Aspek-aspek yang berupa individual, maupun yang bersifat identitas budaya tersebut kemudian disematkan istilah face atau wajah. Penggunaan kata face adalah merupakan bentuk perwujudan dari kesan dan gambar diri. Bagaimana seseorang ingin diperlakukan dan dianggap oleh orang lain (Oetzel \& Ting-Toomey, 2003).

Teori Negosiasi Muka juga dapat dipergunakan kemudian untuk memprediksi daripada perilaku seseorang guna kepentingan penyempurnaan daripada si identitas individu tersebut atau juga bisa disebut dengan facework. Tiap-tiap facework dalam kebudayaan itu memang berbeda. Ada perhubungan antara pesan-pesan baik yang bersifat verbal, begitu juga yang bersifat non verbal. Facework ini kemudian dibagi menjadi budaya individualis dan budaya kolektif (Putra, Razid, Hairunnisa, \& Sabirudin, 2018).

Sedangkan Sari, 2017 menyebutkan bahwasannya Face Negotiation Theory atau Teori Negosiasi Wajah merupakan teori yang dapat memperkirakan seorang manusia dalam menyelesaikan karya wajah dalam sebuah kebudayaan yang berbeda. Wajah, atau juga rupa, itu artinya mengacu pada gambaran diri seseorang ketika ia berada di depan atau hadapan orang lain. Gambaran dari jati diri seseorang. Bagaimana seseorang kemudian ingin melibatkan rasa hormat dia, kehormatan dia, status dia, koneksi dia, kesetiaan dia, ataupun nilai lain yang memiliki jenis yan sama.

Sari juga menyebutkan, bahwasannya dalam Face Negotiation Theory juga terdapat karya wajah yang artinya adalah merupakan perilaku manusia yang kemudian dapat dipergunakan guna membangun wajah atau juga melindungi wajah, bahkan menjatuhkan wajah diri sendiri ataupun wajah orang lain (Sari \& Salam, 2017).

Kemudian (Indreswari, Eswandani, Purwasito, \& Satyawan, 2020) mengutip TingToomey, 2009 bahwasannya facework dapat membantu mengelola konflik dalam hubungan lintas budaya yang bersifat intim maupun sebatas hubungan antar pribadi yang bersifat professional. Facework juga dapat ditrapkan pada komunikasi yang bersifat verbal-non verbal. Bagi mereka yang berusia muda, dapat juga dimanfaatkan dalam pertemanan antar budaya, mengerti proses kebudayaannya, dapat menghadapinya, juga menghindari kekikukan dan perilaku defensif. Mengerti akan penting dan gunanya facework maka bagi usia muda dapat membantu pendekatan dan kebersamaan emosional. Juga dapat memberi pemahaman yang bersifat kritis sehingga dapat mengerti seuatu yang berbeda dalam pendekatan budaya atau konflik di dalamnya dengan beradaptasi dengan perbedaan budaya tersebut.

Sebuah penelitian pun telah menganalisis hubungan emosi dengan asumsi teoritis teori Face Negotiation Theory dan menyelidiki peran penting kemarahan, kasih sayang, dan rasa bersalah dalam memahami jalur kompleks hubungan mereka dengan interpretasi diri, menghadapi kekhawatiran, dan gaya konflik. Hasilnya menunjukkan bahwa emosi memediasi efek dari interpretasi diri dan dalam menghadapi kekhawatiran pada gaya konflik, tetapi perbedaan budaya juga mempengaruhi (Zhang, Ting-Toomey, \& Oetzel, 2014).

Selain itu penelitian lainnya menerapkan teori negosiasi wajah dalam perbandingan lintas budaya dari gaya manajemen wajah, facework, dan konflik antara Ekuador dan Amerika Serikat (AS). Peserta termasuk siswa dari Amerika Serikat dan Ekuador. Peserta menyelesaikan kuesioner yang mengukur preferensi wajah, facework, dan gaya konflik di salah satu dari dua situasi konflik yang diingat yang bervariasi dalam kedekatan relasional. Hasil penelitian menunjukkan bahwa siswa Ekuador dan AS tidak berbeda dalam masalah wajah diri, wajah lain, dan saling berhadapan mereka. Siswa Ekuador dan AS berbeda secara signifikan dalam preferensi mereka untuk facework dan preferensi gaya konflik di dua situasi konflik (Neuliep \& Johnson, 2015).

Selanjutnya, Indreswari, 2020 dalam penelitian lain juga menyatakan, jikalau Face Negotiation Theory dicetuskan oleh Ting Toomey dengan enam asumsi dasar, di antaranya: 
1. Bahwasannya setiap manusia akan mengelola dan menegosiasikan wajah mereka dalam keadaan komunikasi yang berbeda

2. Konsepnya datang bersama masalah ataupun situasi emosional. Dalam kondisi ini, identifikasi akan menjadi pertanyaan besar.

3. Budaya Kolektivistik dan individualistik. Ini tergantung apakah manusia tersebut memilki budaya yang tinggi atau rendah.

4. Nilai yang dianut dalam kolektivistik dan individualistik. Bentuak pilihan individual terhadap face concern apakah self, others, atau bersifat mutual.

5. Dimensi nilai-nilai yang memiliki faktor relasi, situasional bagi si individu. Pemakaian faceworks dalam budaya tertentu.

6. Kemampuan melakukan facework yang baik dalam berinteraksi dengan budaya juga dipengaruhi oleh adanya pengetahuan yang sensitif terkait perbedaan budaya. Pun dengan memiliki kemampuan berkomunikasi dalam budaya yang berbeda.

Terakhir, Nur, 2019 menjelaskan bahwasannya keberhasilan dari Negosiasi Muka, adalah adanya proses untuk menerima atau mengalah dalam kepentingan yang berbeda. Itu semua dilakukan demi meredakan suatu pertentangan Asumsi teori Negosiasi Muka menurut Nur 2019, mengutip (West \& Turner, 2008) kemudian mencakup adanya komponen penting seperti muka, konflik, ataupun budaya.

1. Pentingnya memiliki identitas diri dalam pola interaksi yang bersifat interpersonal. Karena individu akan menengosiasikan identitas secara beda dalam budaya yang beda juga

2. Manajemen konflik akan dimediasi oleh pertama muka dan kedua adalah budaya.

3. Keadaan tertentu yang dapat mengancam citra diri seseorang akan secara jelas ditampilkan atau muka (Nur \& Yasir, 2019).

Ketika muka bersifat positif ataupun negatif sekalipun, komunikator yang terlibat di dalamnya berarti sedang terancam. Dalam keadaan tersebut, komunikan dan komunikator, keduanya akan cenderung mencari bantuan dengan cara mengembalikan muka di antara keduanya. Atau dapat dikatakan inilah yang kemudian disebut sebagai facework. Karena facework adalah bagaimana strategi verbal dan nonverbal yang digunakan guna terpeliharanya dan bagaimana mempertahankan, juga bahkan meningkatkan citra diri dalam scope sosial. Juga dapat dipergunakan untuk menyerang atau mempertahankan orang lain

\section{Metode}

Teknik metodologi penelitian yang dipergunakan adalah teknik analisis data secara tematik dan atau naratif. Ini adalah bagian dari pendekatan metodologi penelitian kualitatif. Menurut (Kriyantono, 2006) Penelitian kualitatif yang memiliki sifat deskriptif akan cenderung menggunakan analisis. Penelitian ini menggunakan kajian literatur berupa penelitian terkait face negotiation theory di berbagai wilayah di Indonesia mulai dari Solo, Semarang, Riau, Bengkalis, dan Tenggarong dengan berbagai informan atau responden penelitian yang mengalami konflik antar etnis di wilayah tersebut.

Landasan teori nantinya akan dimanfaatkan sebagai acuan supaya fokus penelitian akan menjadi sesuai dengan fakta di lapangan dalam bentuk penelitian terdahulu. Metode deskriptifkualitatif adalah metode yang memberikan gambaran atau deskripsi tentang variabel dari sebuah fenomena yang diteliti dimana penelitian jenis ini memiliki ciri menitikberatkan pada observasi dan suasana alamiah (natural setting) (Elvinaro, 2014).

\section{Hasil Penelitian dan Pembahasan}

Semua penelitian bertitik tolak memang pada bagaimana proses facework penyelamatan wajah dan pengintimidasian wajah. Berkaca pada penelitian-penelitian terdahulu yang telah dicantumkan dalam pendahuluan, terdapat beberapa unsur yang tidak terbahas secara utuh jika 
menggunakan Face Negotiation Theory. Satu di antaranya adalah tidak semua jurnal memberi analisa terkait budaya tinggi dan rendah yang mana itu menjadi ciri khas perbedaan yang dipakai dalam Face Negotiation Theory. Selain itu, analisa terkait budaya kolektivistik maupun individualistik tidak semua jurnal kemudian menonjolkannya, melainkan hanya sebatas pembahasan terkait budaya kolektivistik yang memang kental di negara Asia, termasuk Indonesia. Juga adanya sub variabel independen dan interdependen yang dapat jauh mendeskirpsikan facework seseorang.

Penelitian jurnal yang telah disebutkan kebanyakan mencari jalan atau menggiring akan hasilnya mesti dalam kata maaf atau sebuah rekonsiliasi. Karena semua jurnal diperoleh dari jurnal nasional terindeks dan ditulis juga oleh orang Indonesia yang notabene menganut budaya kolektivistik yang mengakibatkan hal tersebut. Tidak ada satu pun yang mengidentifikasi sebuah konflik yang kemudian berujung pada bukan hal yang berbentuk memaafkan.

Griffin menyebutkan bahwasannya Teori negosiasi wajah Stella Ting-Toomey menjelaskan berbagai gaya manajemen konflik yang digunakan oleh orang-orang dari budaya yang berbeda. Teori ini menjelaskan dan memprediksi perbedaan budaya dalam menanggapi konflik. TingToomey berasumsi bahwa orang dari setiap budaya selalu menghadapi negosiasi. Istilah itu adalah metafora untuk citra diri publik kita - cara kita ingin orang lain melihat dan memperlakukan kita. Facework mengacu pada "pesan verbal dan nonverbal spesifik yang membantu mempertahankan dan memulihkan wajah yang hilang, dan untuk menjunjung tinggi serta menghormati keuntungan wajah." Ketika orang cenderung menggunakan jenis pekerjaan wajah yang sama, tidak peduli apa perselisihan, dia menyebutnya sebagai gaya konflik mereka (Griffin, Ledbetter, \& Sparks, 2015).

Ting-Toomey mendasarkan teori negosiasi wajahnya pada perbedaan antara kolektivisme dan individualisme. Wajah adalah perpanjangan dari konsep diri: sumber daya berbasis identitas yang rentan. Pemulihan wajah yang mementingkan diri sendiri adalah strategi pengerjaan wajah yang digunakan untuk mengintai tempat unik dalam hidup, mempertahankan otonomi, dan mempertahankan diri dari hilangnya kebebasan pribadi. Tidak mengherankan, pemulihan wajah adalah strategi wajah yang khas di seluruh budaya individualistis. Memberikan perhatian pada orang lain adalah strategi kerja wajah yang digunakan untuk mempertahankan dan mendukung kebutuhan orang lain akan inklusi. Itu berarti berhati-hati untuk tidak mempermalukan atau mempermalukan orang lain di depan umum. Memberi wajah adalah karakteristik strategi wajah di seluruh budaya kolektivis (Griffin, Ledbetter, \& Sparks, 2015).

Ting-Toomey awalnya mengidentifikasi lima respons berbeda terhadap situasi di mana ada ketidakcocokan antara kebutuhan, minat, atau tujuan. Lima gaya konflik adalah menghindari (menarik), mewajibkan (menampung), mengkompromikan (tawar-menawar), mendominasi (bersaing), dan mengintegrasikan (pemecahan masalah). Kebanyakan penulis Barat mengacu pada lima gaya manajemen konflik yang sama (Griffin, Ledbetter, \& Sparks, 2015). 


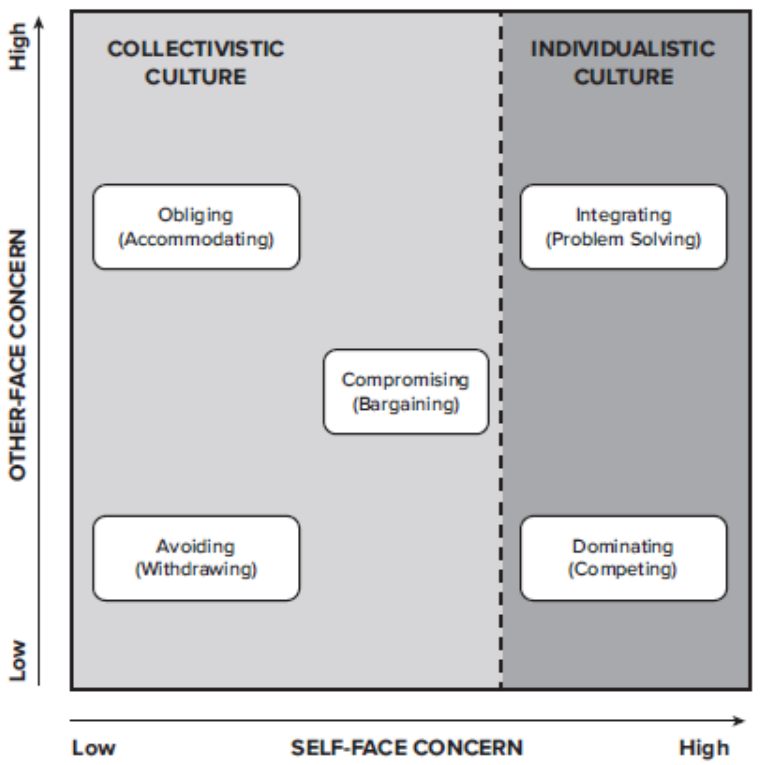

FIGURE 35-1 Five Styles of Conflict Management

Based on Ting-Toomey et al., "Culture, Face Maintenance, and Styles of Handling Interpersonal Conflict: A Study in Five Cultures"

Gambar 1. Other Face dan Self Face dalam Budaya Kolektivistik dan Individualistik (Griffin, Ledbetter, \& Sparks, 2015).

Littlejohn menyebutkan bahwasannya orang bukanlah klon budaya. Sama seperti budaya yang bervariasi sepanjang skala yang ditambatkan oleh orientasi individualistis atau kolektivis, demikian pula anggotanya. Ting-Toomey sekarang menekankan bahwa orang-orang dalam budaya tertentu berbeda pada penekanan relatif yang mereka tempatkan pada kemandirian individu atau solidaritas kelompok. Dia menggunakan istilah diri independen dan interdependen untuk merujuk pada "sejauh mana orang memahami diri mereka sendiri sebagai relatif otonom dari, atau terhubung dengan, orang lain (Griffin, Ledbetter, \& Sparks, 2015).

Realitas relasional perbedaan citra diri dalam dua budaya direpresentasikan dalam diagram berikut. Setiap lingkaran $(\bullet)$ mewakili konstruasi diri seseorang yang dibesarkan dalam masyarakat kolektivis yang mensosialisasikan anggotanya agar saling bergantung dan mencakup semua orang yang menghadapi masalah. Setiap segitiga ( $\mathbf{\Lambda})$ melambangkan konstruksi diri seseorang yang dibesarkan dalam budaya individualistis yang menekankan kemandirian dan kemandirian. (Griffin, Ledbetter, \& Sparks, 2015).

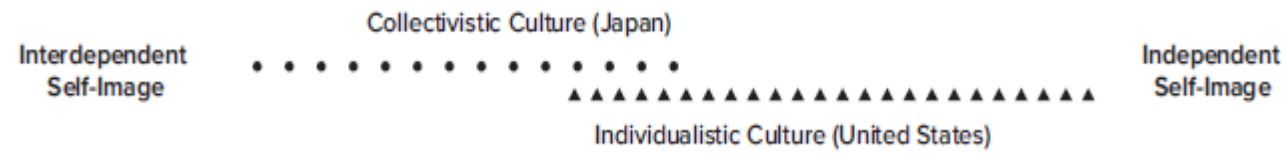

Gambar 2. Bagan untuk menentukan Self Construal (Griffin, Ledbetter, \& Sparks, 2015).

Perbedaan antara budaya kolektivistik dan budaya individualistik tetap penting karena budaya memiliki pengaruh yang kuat terhadap pembentukan diri individu. Tetapi rasa identitas individu itu selangkah lebih dekat dengan gaya yang disukai orang tersebut dalam menangani konflik, jadi ini memprediksi perilaku perselisihan lebih baik daripada budaya umum (Griffin, Ledbetter, \& Sparks, 2015).

Type of $\rightarrow$ Self- $\rightarrow$ Face $\rightarrow$ Conflict

Culture Construal Concern Style 
Teori ini memberikan dasar untuk memprediksi bagaimana orang akan menyelesaikan pekerjaan wajah dalam budaya yang berbeda, terutama saat mengelola konflik. Wajah mengacu pada citra diri seseorang di kehadiran orang lain. Ini melibatkan perasaan hormat, kehormatan, status, koneksi, kesetiaan, dan nilai-nilai serupa lainnya. Dengan kata lain, wajah berarti gambar yang Anda inginkan atau identitas yang dianggap orang lain untuk Anda dalam situasi sosial tertentu. Budaya sangat menentukan identitas apa yang diinginkan dalam suatu situasi. Pekerjaan muka adalah perilaku komunikasi yang digunakan orang untuk membangun dan melindungi wajah mereka sendiri dan untuk melindungi, membangun, atau mengancam wajah orang lain (Griffin, Ledbetter, \& Sparks, 2015).

Dalam (Littlejohn, Karen, \& Oetzel, 2017) disebutkan bahwasannya wajah adalah perhatian universal, tetapi bagaimana wajah didefinisikan dan cara pengerjaan wajah diselesaikan sangat bervariasi dari orang ke orang dan budaya ke budaya. Semua budaya memiliki cara untuk mencapai pekerjaan pencegahan dan restoratif. Pekerjaan wajah preventif melibatkan komunikasi yang dirancang untuk melindungi seseorang dari perasaan yang mengancam wajah pribadi atau kelompok.

Wajah biasanya menjadi masalah dalam situasi konflik. Saat Anda mengalami konflik dengan orang lain, rasa hormat dan kehormatan sering kali dikompromikan. Ancaman menghadapi dapat terjadi dalam situasi yang ditandai dengan: (1) persaingan atau keinginan untuk menang; (2) merasa marah atau tidak yakin dalam beberapa hal; (3) nilai, pendapat, atau sikap yang bertentangan. Pekerjaan muka adalah bagian rutin dari komunikasi konflik. Seringkali penampilan wajah negatif dan berupa serangan terhadap orang lain (Littlejohn, Karen, \& Oetzel, 2017).

Ada tiga tingkat faktor yang memengaruhi kekuatan kekhawatiran diri dan orang lain. Di tingkat budaya, individualisme-kolektivisme adalah faktor kunci - apakah fokusnya pada identitas individu atau identitas kelompok? Anggota budaya individualis biasanya melakukan lebih banyak pekerjaan wajah yang mengakui orang sebagai individu otonom dan memiliki orientasi wajah-diri yang tinggi. Mereka menganggap diri mereka penting di luar orang lain dan bekerja untuk membangun harga diri mereka sendiri serta orang lain. Sebaliknya, dalam budaya kolektivis, pekerjaan wajah berorientasi pada kelompok, dan wajah lain ditekankan (Littlejohn, Karen, \& Oetzel, 2017).

Dalam hal gaya konflik, baik individualis maupun kolektivis lebih suka gaya berkolaborasi. Namun, gaya sekunder mereka berbeda. Individu juga menggunakan gaya bersaing, sementara kolektivis menyukai menghindari, mengakomodasi, dan berkompromi. Individualis akan menggunakan serangan pribadi yang lebih langsung dan mungkin mencoba melindungi atau membangun kembali wajah - wajah mereka dan orang lain — dengan menunjukkan rasa hormat pribadi. Kolektivis, di sisi lain, akan menggunakan lebih sedikit serangan pribadi dan akan lebih tidak langsung dalam konflik. Mereka mungkin menghindari masalah yang sedang dihadapi, membicarakannya, mendiskusikan masalah sampingan, mengambil lebih banyak waktu untuk langsung ke intinya, dan umumnya berbicara dengan cara yang membangun rasa kelompok atas diri mereka sendiri. Individualis dalam konflik ingin melewatinya dengan menyelesaikan masalah atau menyelesaikan perselisihan. Kolektivis, sebaliknya, lebih tertarik untuk memperkuat hubungan. Kolaborasi dan kompromi memiliki arti yang berbeda dalam budaya yang berbeda ini. Bagi individualis, kolaborasi dan kompromi adalah cara untuk memecahkan masalah, tetapi bagi kolektivis, itu adalah sarana untuk membangun hubungan (Littlejohn, Karen, \& Oetzel, 2017).

Dominance (Self-face)

Defend-Stand up for one's opinion; try to persuade the other.

Express emotion - Verbally express one's feelings or emotions.

Aggression-Make a direct or passive effort to hurt the other. 
Avoidance (Other-face)

Give in-Accommodate the other's wishes.

Pretend-Act like the conflict doesn't exist.

Third party - Seek an outside party to help resolve the conflict.

Integration (Mutual-face)

Apologize-Say sorry for past behavior.

Private talk-Avoid public confrontation.

Remain calm-Stay composed during the conflict.

Problem solve-Engage in behaviors to join perspectives together.

Respect-Demonstrate regard for the other by listening.

KEY TO FACENEGOTIATION THEORY PREDICTIONS
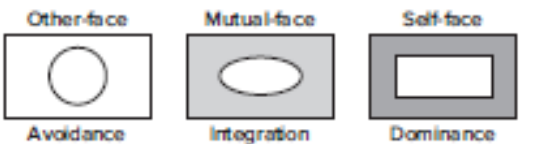

RESEARCH RESULTS IN FOUR-CULTURE STUDY

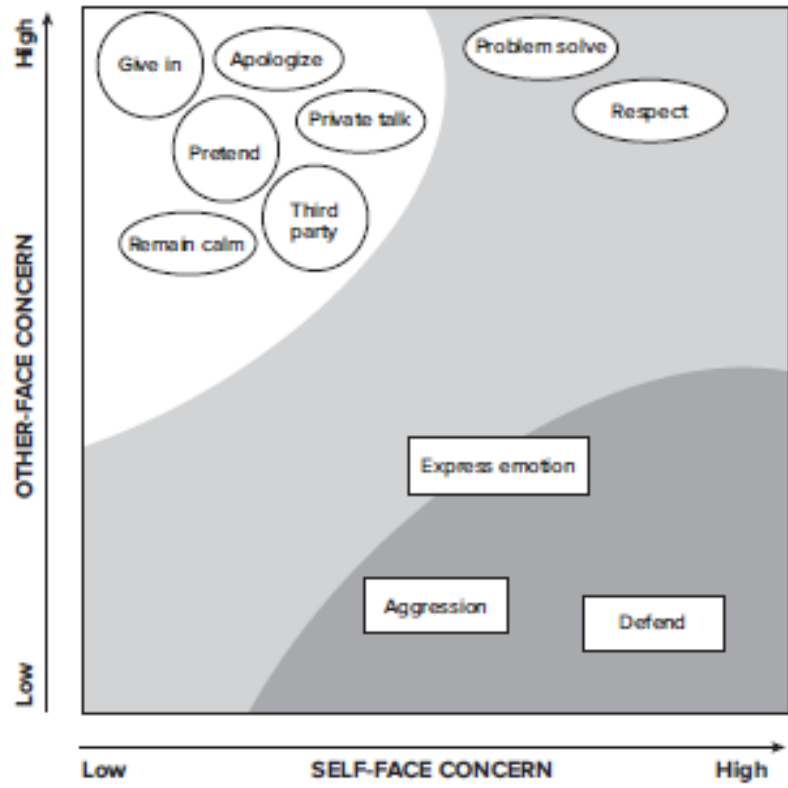

FIGURE 35-2 Comparison of Theory Predictions and Research Results

Based on Oetzel, Garcia, and Ting-Toomey, "An Analysis of the Relationships Among Face

Concerns and Facework Behaviors in Perceived Conflict Situations: A Four-Culture Investigation",

Gambar 3. Prediksi Face Negotiation Theory (Griffin, 2015)

Kemudian Dainton menyatakan bahwa wajah mencakup dua dimensi: positif dan negatif. Wajah positif mencakup kebutuhan untuk disukai, dihargai, dan dikagumi; wajah negatif menekankan keinginan untuk bertindak bebas tanpa kendala atau paksaan dari orang lain. 
Wajah bukanlah konsep satu arah; wajah juga mencakup pengakuan bahwa orang-orang di sekitar kita memiliki kebutuhan wajah mereka sendiri. Kesadaran akan kebutuhan wajah orang lain (baik positif maupun negatif) dikenal sebagai memiliki perhatian wajah (Dainton \& Zelley, 2018).

Inti dari Face Negotiation Theory adalah dimensi individualisme-kolektivisme, konteks tinggi-konteks rendah, dan jarak kekuasaan seperti yang dijelaskan sebelumnya dalam bab ini Face Negotiation Theory berpendapat bahwa anggota budaya individualistis, konteks rendah terutama berfokus pada wajah negatif - yaitu, mereka lebih suka menampilkan diri sebagai percaya diri, mengarahkan diri sendiri, dan mandiri (Ting-Toomey \& Kurogi, 1998). Sebaliknya, anggota budaya kolektivistik dan konteks tinggi terutama menekankan wajah positif, menampilkan diri mereka sebagai orang yang disukai, kooperatif, dan tertarik dalam membangun hubungan. Demikian pula, anggota budaya jarak kekuasaan rendah lebih suka melihat individu sebagai sederajat, sedangkan anggota budaya jarak kekuasaan tinggi menerima dan bergantung pada hierarki dan perbedaan status (Ting-Toomey, 2005 dalam (Dainton \& Zelley, 2018)).

Berkenaan dengan Face Negotiation Theory, konflik didefinisikan sebagai ketidakcocokan nilai, harapan, proses, atau hasil yang dirasakan atau aktual antara dua atau lebih. Kelima gaya konflik ini bervariasi dalam dua dimensi: ketegasan (perhatian pada diri sendiri) dan kerjasama (perhatian pada orang lain). Mereka yang mempraktikkan penghindaran kekurangan ketegasan dan kerja sama; mereka menarik diri dari atau berusaha menghindari konflik sama sekali. Dengan demikian, hanya ada sedikit perhatian untuk diri sendiri atau orang lain. Individu dengan gaya akomodatif bekerja sama dengan orang lain tetapi menunjukkan sedikit ketegasan - biasanya menuruti permintaan pasangannya. Sebaliknya, mereka yang bersaing dalam situasi konflik sangat asertif tetapi kurang bekerja sama; mereka mendorong sudut pandang mereka pada orang lain, kadang-kadang sampai mengorbankan hubungan sama sekali. Seseorang dengan gaya kompromi memiliki perhatian sedang terhadap diri sendiri dan orang lain; individu ini agak tegas dan cukup kooperatif. Kompromi biasanya melibatkan kesediaan untuk melepaskan beberapa tuntutan untuk mendapatkan yang lain. Akhirnya, individu dengan gaya berkolaborasi memiliki rasa hormat yang tinggi terhadap diri sendiri dan orang lain, membuat orang tersebut sangat asertif dan juga sangat kooperatif. Kolaborasi terjadi ketika seseorang secara aktif berupaya menciptakan solusi baru yang memenuhi kepentingan kedua mitra tanpa harus berkorban saat berkompromi. Perhatikan bahwa gaya konflik bukanlah sifat yang tetap; sebaliknya, ini adalah respons yang disukai seseorang terhadap konflik dalam situasi tertentu. Anda dapat mengubah gaya konflik Anda tergantung pada pasangan yang terlibat dan keadaan yang ada (Dainton \& Zelley, 2018).

Gaya ekspresif emosional mengacu pada respons afektif terhadap konflik yang bertentangan dengan respons kognitif. Artinya, ekspresi emosional menekankan keinginan seseorang untuk bereaksi terhadap perasaannya atau "reaksi nalurinya". Seseorang yang mengandalkan gaya pasif-agresif secara diam-diam mencoba membuat pasangannya merasa bersalah. Agresi pasif lebih aktif daripada menghindari situasi sama sekali tetapi kurang aktif daripada secara terbuka menangani konflik; individu yang pasif-agresif hanya memberikan petunjuk yang menyalahkan dari masalah tersebut. Terakhir, kecenderungan untuk mengandalkan bantuan pihak ketiga berarti orang tersebut lebih nyaman meminta orang di luar hubungan untuk membantu mengelola konflik. Misalnya, dalam konteks komunikasi bisnis, orang Asia sering menggunakan perantara seperti itu untuk membantu melestarikan wajah (Dainton \& Zelley, 2018).

Orang Amerika biasanya menggunakan strategi konflik konfrontatif dan mendominasi dengan orientasi menang-kalah yang lebih kuat untuk mempertahankan wajah diri (TingToomey, Conflict Face-Negotiation Theory; Tracking Its Evolutionary Journey, 2017). Sebaliknya, orang Asia lebih memilih penghindaran konflik dalam upaya menjaga muka bersama. Lebih tepatnya, orang Taiwan dan Cina lebih mengandalkan gaya konflik yang berkompromi; ketika bekerja dengan anggota dalam kelompok (Jepang), orang Jepang juga mengandalkan penghindaran konflik. Khususnya, bagaimanapun, orang Jepang mencerminkan gaya konflik orang Amerika yang lebih mendominasi ketika berhadapan 
dengan rekan luar kelompok (non-Jepang). Kemampuan untuk beralih di antara gaya yang bergantung pada afiliasi dalam kelompok / luar dapat membantu menjelaskan kompetensi Jepang saat berkomunikasi dalam hubungan bisnis global (Dainton \& Zelley, 2018).

Dari penjelasan panjang lebar yang dirangkum dari tiga buku di atas, jurnal pertama hanya sebatas menjabarkan terkait memanajemen konflik dan menguragi perbedaan-perbedaan dengan cara melebur, menghargai perbedaan atau toleransi, memiliki rasa empati dan simpati, Kemudian jurnal kedua hanya sebatas upaya dalam Face-restoration yakni strategi facework yang digunakan untuk dapat mempertahankan mimik wajah saat berinteraksi, dan dapat menyelamatkan wajah kita dari ancaman wajah lain untuk melakukan pembelaan diri.

Kemudian dalam jurnal penelitian lain ada juga yang menyertakan konsep avoiding, obliging, comprimising, dominating, dan integrating dalam penyelesaian konflik menggunakan analisis Face Negotiation Theory. Ada juga yang menerapkan konsep welas asih dalam diskusi yang diangkat dalam dialog antar budaya. Dimana peserta kemudian dinilai dalam kemampuan untuk melakukan pemikiran kritis, kemampuan untuk mengkomunikasikan perasaan, pendapat, keterbukaan, dan empati terhadap budaya lain. Termasuk bagaimana persepsi yang diperoleh diperoleh melalui dialog proses, serta pemahaman wajah- penggunaan pekerjaan oleh peserta sambil bertanggung jawab ding untuk diskusi konflik. Setelah itu, siswa penyok diundang untuk mengungkapkan pengampunan mereka untuk membangun tindakan welas asih melalui pengampunan total (Afif, 2019). Proses ini penting sebagai upaya untuk menciptakan komptensi antar budaya. bagi siswa, serta menghilangkan prasangka, stereotip, dan etnosentrisme di antara komunitas yang beragam, yang akan meminimalkan terjadinya konflik budaya.

Karena tindakan welas asih mendukung kompetensi antar budaya. Welas asih adalah kemampuan memaafkan yang tak termaafkan, sifat yang menunjukkan sisi humanis seseorang. Welas asih diperoleh melalui pengampunan total. Pemberian maaf adalah proses komunikasi penyelesaian konflik. Hal itu dapat dilakukan melalui pendekatan negosiasi wajah sebagai upaya untuk memahami dan memprediksi bagaimana orang dalam budaya yang berbeda berperilaku terhadap konflik. Melalui dialog antarbudaya dapat diperoleh kompetensi antarbudaya serta pembinaan tindak welas asih (Afif, 2019).

Proses ini penting sebagai upaya menyelesaikan konflik budaya yang sering terjadi di Indonesia. Dalam dialog ini siswa diajak untuk memahami wajah individu dari budaya yang berbeda, mengkomunikasikan perbedaan mereka, menjadi kritis, berpikiran terbuka, menghormati dan siap untuk proses pengampunan total. Keberhasilan menumbuhkan welas asih dalam kompetensi lintas budaya siswa akan membantu menghilangkan tindakan seperti prasangka buruk, stereotipe, dan etnosentrisme di antara keragaman masyarakat serta mencegah konflik budaya, yang akan membawa dampak besar dalam hubungan lokal, bahkan internasional.

Dalam jurnal lain dikatakan bahwasannya Indonesia menganut budaya kolektivistik. Sebagian besar etnis Jawa dan NTT juga menganutnya budaya kolektif. Namun, sebagian besar merupakan representasi negara dilihat melalui lensa budaya Jawa, mencerminkan dominasi dan menciptakan kondisi yang rawan konflik budaya karena pilihan yang terbatas dan terpaksa bagi mereka budaya minoritas di Indonesia. Kondisi ini terlihat jelas khususnya dalam pemilihan politik, di mana banyak warga Indonesia memilih pemimpin berdasarkan dirinya komunitas daripada kemampuan mereka; Kondisi tersebut semakin parah dengan dimasukkannya isu-isu keagamaan sorotan. Konflik karena favoritisme komunal juga terjadi antar pemuda, seperti bentrok antar sesame mahasiswa dari etnis yang berbeda serta penolakan etnis tertentu untuk tinggal di asrama mahasiswa. Favoritisme etnis berbasis identitas paling kuat jika dibandingkan dengan identitas budaya lainnya, seiring dengan terbentuknya identitas etnis dalam hubungan kekeluargaan dan sejak usia muda. Riset di Indonesia telah menunjukkan banyak siswa mengalami diskriminasi berdasarkan budaya perbedaan seperti penampilan fisik, norma budaya dan keyakinan; menghasilkan banyak dari itu siswa pendatang yang tinggal di asrama yang diperuntukkan bagi mereka dari etnis yang sama karena rasa takut diskriminasi (Indreswari, Eswandani, Purwasito, \& Satyawan, 2020). 
Salah satu studi Face Negotiation Theory mengemukakan perlunya variabel penyeimbang dalam penelitian tentang budaya dilakukan, terutama antara budaya individualis, kolektivis dan komunal, sehingga hasil penelitian menjadi efektif dan seimbang. Variabel penyeimbang adalah persepsi, makna kognitif, penggunaan bahasa dan terjemahan yang sesuai atau setara antara peneliti dan responden. Ini juga sesuai dengan elemen teks CDA, praktik diskursif, dan praktik sosial. Dalam kasus Indonesia, konteks budaya rendah dan tinggi juga harus ditambahkan sebagai penyeimbang variabel. Orang Jawa dikenal sebagai budaya konteks tinggi dan NTT adalah budaya konteks rendah. Orang Jawa menganggap pentingnya suatu keadaan secara keseluruhan ketika mengartikan suatu peristiwa, pembuatan Budaya ini memiliki kecenderungan kesulitan dalam menyampaikan pesan non verbal dan melihat pentingnya perilaku tidak langsung. Sedangkan bagi mahasiswa NTT, mereka melihat pentingnya eksplisit konten, sehingga tanggapan langsung sangat dihargai (Indreswari, Eswandani, Purwasito, \& Satyawan, 2020).

\section{Simpulan}

Dalam mendefinisikan Face Negotiaton Theory, fase yang berkembang pertama-tama adalah mencari tahu terlebih dahulu terkait Type of Culture. Di mana unsur kolektivistik dan individualistik yang berada di dalamnya, Kemudian mendefinisikan Self-Construal, di mana itu adalah merupakan sejauh mana seseorang kemudian mengganggap diri mereka sebagai diri yang relative otonom dari, atau terhubung dengan lain orang. Dibuktikan dengan indikator independent dan interdependent nya, lalu Face Concern, di mana itu merujuk pada bagaimana seseorang dapat menghargai diri sendiri, menghargai orang lain atau saling bertatap muka. Dan yang terakhir adalah Conflict Style yang didefinisikan sebagai 13 kecenderungan seseorang dalam menghadapi konflik. Dalam fenomena ke-Indonesia-an, rata-rata jurnal akan menemukan fakta biasanya masyarakat Indonesia dalam menentukan sikap disaat konflik adalah integration atau mutual - face. Dimana ciri di dalamnya adalah Apologize, Private talk, Remain calm, Problem solve, dan Respect. Yang mana perilaku tersebut adalah ciri khas budaya kolektivistik yang memang dianut oleh masyarakat Indonesia secara umum.

Guna melengkapi konsep yang belum dijelaskan. Saran akademis dalam penelitian yang menggunakan Face Negotiation Theory sebagai analis, juga berisikan kontribusi lebih dapat mengeksplorasi konsep yang belum banyak ditemukan atau diteliti seperti keberadaan indikator interdependen dan independent. Apakah masyarakat Indonesia dalam self construal nya benar-benar hanya terpaku pada budaya kolektivistik tanpa adanya otonomi sendiri sebagai seorang individu. Face Negotiation Theory dapat menjadi acuan bagaimana memahami komunikasi antarbudaya. Mengingat perbedaan budaya itu dapat menyebabkan gesekan antar etnis. Mengerti budaya lain akan lebih memudahkan berinteraksi dengan orang lain.

\section{Daftar Kepustakaan}

Afif, A. (2019). The Concept of Welas Asih Through Face Negotiation as Intercultural . Komunitas: Interational Journal of Indonesian Society and Culture 12 (1), 77-85.

Dainton, M., \& Zelley, E. (2018). Applying Communication Theory for Professional Life: a Practical Introduction 4th Edition. Thousand Oaks: SAGE Publication, Inc.

Elvinaro, A. (2014). Metodologi Penelitian untuk Public Relation Kuantitatif dan kualitatif. Bandung: Simbiosa Rekatama Media.

Griffin, E., Ledbetter, A., \& Sparks, G. (2015). A First Look at Communication Theory (9th Ed). New York: McGraw-Hill Education.

Indreswari, Eswandani, P., Purwasito, A., \& Satyawan, A. (2020). Face Negotiation in Conflict Resolution and Friendship Building among Indonesia's Javanese and NTT Youth in Solo. International Journal of Innovation, Creativity and Change Volume 12 Issue 10. 
Kriyantono, R. (2006). Teknik Praktis Riset Komunikasi. Jakarta: Kencana Prenada Media Grup.

Littlejohn, S., Karen, A. F., \& Oetzel, J. G. (2017). Theories of Human Communication (11th Edition). Belmont, CA: Thomson Wadsworth.

Neuliep, J., \& Johnson, M. (2015). United States face, facework, and conflict styles during interpersonal conflict: An application of face-negotiation theory. Journal of Intercultural Communication Research, 1-9.

Nur, V. W., \& Yasir. (2019). Negosiasi Muka dalam Komunikasi Antarbudaya Masyarakat Transmigran (Jawa) dan Penduduk Lokal (Melayu) di Desa Kuala Kilan Kecamatan Batang Cenaku Kabupaten Indragiri Hulu Riau. JOM FISIP Vol.6: Edisi II.

Oetzel, J., \& Ting-Toomey, S. (2003). Face concerns in interpersonal conflict: A crosscultural empirical test of the face negotiation theory. Communication research, 30(6), 599-624.

Putra, Razid, K., Hairunnisa, \& Sabirudin. (2018). Pola Komunikasi Masyarakat Desa Bangunrejo Kecamatan Tenggarong Seberang dalam Meredam Konflik Etnis. eJournal Ilmu Komunikasi, 6 (1) 2018, 441-455.

Sari, M. Y., \& Salam, N. E. (2017). Komunikasi Antarbudaya Studi Negosiasi Wajah dalam Interaksi Etnik Batak dan Etnik Minang di Duri Keluraham Gajah Sakti Kecamatan Mandau Kabupaten Bengkalis. JOM FISIP Vol.4 No.2.

Ting-Toomey, S. (2017). Conflict Face-Negotiation Theory; Tracking Its Evolutionary Journey. Routledge.

Ting-Toomey, S., \& Kurogi, A. (1998). Facework competence in intercultural conflict: An updated face-negotiation theory. International journal of intercultural relations, 22(2) Elsevier, 187-225.

West, R., \& Turner, L. (2008). Pengantar Teori Komunikasi:Analisis dan Aplikasi (Introduction Communication Theory: Analysis and Application. Jakarta: Salemba Humanika.

Zhang, Q., Ting-Toomey, S., \& Oetzel, J. (2014). Linking Emotion to the Conflict FaceNegotiation Theory: A U.S.-China Investigation of the Mediating Effects of Anger, Compassion, and Guilt in Interpersonal Conflict. Human Communication Research, 373-395. 